\title{
Petrological and chemical variability of peridotite xenoliths from the Cameroon volcanic line, West Africa: an evidence for plume emplacement
}

\author{
Kyoko N. MATSUKAGE, ${ }^{* * *}$ and Mami OYA ${ }^{* *}$ \\ *Geodynamics Research Center, Ehime University, 2-5 Bunkyo-cho, \\ Matsuyama, Ehime 790-8577, Japan \\ ${ }^{* *}$ Department of Earth Sciences, Ibaraki University, 2-1-1 Bunkyo, \\ Mito, Ibaraki 310-0056, Japan
}

\begin{abstract}
Peridotite xenoliths from the Cameroon volcanic line (CVL), which is a $1600-\mathrm{km}$-long volcanic chain on the continental margin of West Africa and the Gulf of Guinea, exhibit regional variations in petrography, mineral chemistry, and equilibrium temperature. The xenoliths are mainly composed of spinel lherzolite, spinel harzburgite, dunite, and small amounts of wehrlite and websterite. Lherzolite and harzburgite are similar in texture, and the $\mathrm{MgO}$ and $\mathrm{Cr}_{2} \mathrm{O}_{3}$ components in these minerals increase with a decrease in the $\mathrm{Al}_{2} \mathrm{O}_{3}$ and $\mathrm{Na}_{2} \mathrm{O}$ components and the modal abundance of clinopyroxene. This feature can be explained by a process of the partial melting of pyrolitic lherzolite and subsequent melt extraction in shallow mantle at a depth of $30-80 \mathrm{~km}$. The Bioko, which is located near the center of the CVL, is distinctive from other regions (Annobon, Principe, Mt. Cameroon, $\mathrm{Oku}$, and Ngaoundere) because of the higher degree of partial melting of residual peridotites. The estimated degree of partial melting in Bioko was about 25-30\%, while in other areas it was less than $25 \%$. Bioko was also characterized by the amount of cumulus dunite and wehrlite. The equilibrium temperatures of the xenoliths, as determined by a two-pyroxene geothermometer, were higher at the center of the CVL (e.g., about $1000{ }^{\circ} \mathrm{C}$ in Bioko) and gradually decreased toward the margins of the CVL (e.g., they were about $850{ }^{\circ} \mathrm{C}$ in Annobon, the margin of the oceanic area). These observations indicate that extensive igneous activity occurred at the uppermost mantle under the Bioko area, near the center of the CVL. Based on our study and previous isotope studies of volcanic rocks, we conclude that the regional variations in the CVL mantle were formed by the upwelling and emplacement of a deep hot plume about $120 \mathrm{Ma}$, which caused the opening of the Atlantic Ocean.
\end{abstract}

Keywords: Peridotite, Mantle xenolith, Plume, Passive margin, Mantle heterogeneity

\section{INTRODUCTION}

Magmas of the Cameroon volcanic line (CVL) are known to carry large amounts of peridotite and pyroxenite xenoliths (e.g., Lee et al., 1996). Peridotite xenoliths provide direct information about the features and evolution of the chemical and petrological variations in the upper mantle beneath the volcanic line. Although peridotite-xenolith bearing magmas mostly occur in hotspots in both continental and oceanic plates (e.g., Nixon, 1987), a few magmas in subduction zones at oceanic-oceanic (oceanic-arc) and oceanic-continental margins have been known to carry peridotite xenoliths. For example, peridotite xenoliths from the uppermost mantle have been reported in active

doi:10.2465/jmps.090304

K.N. Matsukage, kmatsu@sci.ehime-u.ac.jp Corresponding author margins such as the Japan arcs and the Philippines (e.g., Vidal et al., 1989; Abe et al., 1998; Arai and Kida, 2000).

Cameroon volcanoes erupt in a unique tectonic setting with a passive margin between continental crust and oceanic crust. This area is well known for an upwelling deep mantle plume that controlled the separation of Africa from South America about $120 \mathrm{Ma}$ (e.g., Bruke and Dewey, 1973; Halliday et al., 1990). The purpose of our study is to determine the chemical and petrological features of the upper mantle from such a unique tectonic setting as the CVL, and to understand the variability in the evolution of Earth's mantle. In this study, we describe the systematic spatial variation in the modal composition and mineral chemistry of the uppermost mantle under the CVL. We infer that the peridotite xenoliths of the CVL are samples from the lithosphere heated by an upwelling 
hot-plume of deep origin beneath the previous continental-continental boundary between Africa and South America at the time of the opening of the Atlantic Ocean.

\section{GEOLOGICAL AND TECTONIC BACKGROUND}

The Cameroon volcanic line (CVL) is a $1600-\mathrm{km}$-long volcanic chain of alkali basalt on the continental passive margin of West Africa and the Gulf of Guinea (Fig. 1). It consists of 12 main volcanic centers from the Tertiary Pe$\operatorname{riod}(\sim 37 \mathrm{Ma})$ to the present age. The origin of the CVL has been controversial because of its complex geologic history, owing to its unique tectonic setting(s) (e.g., Fitton, 1980; Morgan, 1983; Halliday et al., 1990; PoudjomDjomani et al., 1997). It is considered that the former RRR (ridge-ridge-ridge) triple junction that resulted from mantle plume existed in this area when the Atlantic Ocean opened about $120 \mathrm{Ma}$ in the Early Cretaceous (Burke and Dewey, 1973; Halliday et al., 1990). The Benue Trough (Fig. 1) is a former rift valley that formed one of the triple junctions, while the other two arms formed the Mid-Atlantic Ridge (Burke et al. 1971). The Benue Trough failed to develop, while the other two arms ultimately gave rise to the Atlantic Ocean (e.g., Burke et al. 1971; Fitton, 1980). At present, the hotspot volcano of this mantle plume is considered to be located at St. Helena in the Atlantic Ocean (e.g., Fitton, 1980; O'Connor and le Roex, 1992). The CVL has been erupting slightly south of the Benue Trough (Fig. 1).

Fitton and Dunlop (1985) measured and compiled the $\mathrm{K}-\mathrm{Ar}$ age of volcanic rocks of the $\mathrm{CVL}$ and discussed the history of the Cameroon line magmatism. Because the Cameroon line is a linear volcanic chain, it has been speculated that it might have been formed as a hotspot trail like the Hawaiian Islands when the Atlantic Ocean began opening about $120 \mathrm{Ma}$. As shown in Fitton and Dunlop (1985), however, the K-Ar age of the volcanic rocks is obviously younger than the age of the onset of the Atlantic Ocean opening. Neither systematic age progressions nor significant age differences exist between continental and oceanic volcanic rocks from this area (e.g., Marzoli et al., 2000). Moreover, individual volcanic centers have continued to be active for long periods (Fitton and Dunlop, 1985). This observation is not consistent with the conventional hotspot model. The intrusive (granite) complex near the Mandara area in the continental sector, at about $65 \mathrm{Ma}$, is the oldest magmatism of the Cameroon line (Fitton, 1983 and references there in), with volcanism starting at Mandara about $37 \mathrm{Ma}$. The next oldest magmatism is Principe in the oceanic sector (Fitton and Dunlop, 1985). Mt. Cameroon at the center of the CVL (at the boundary of the continent and ocean, see Fig. 1) is still

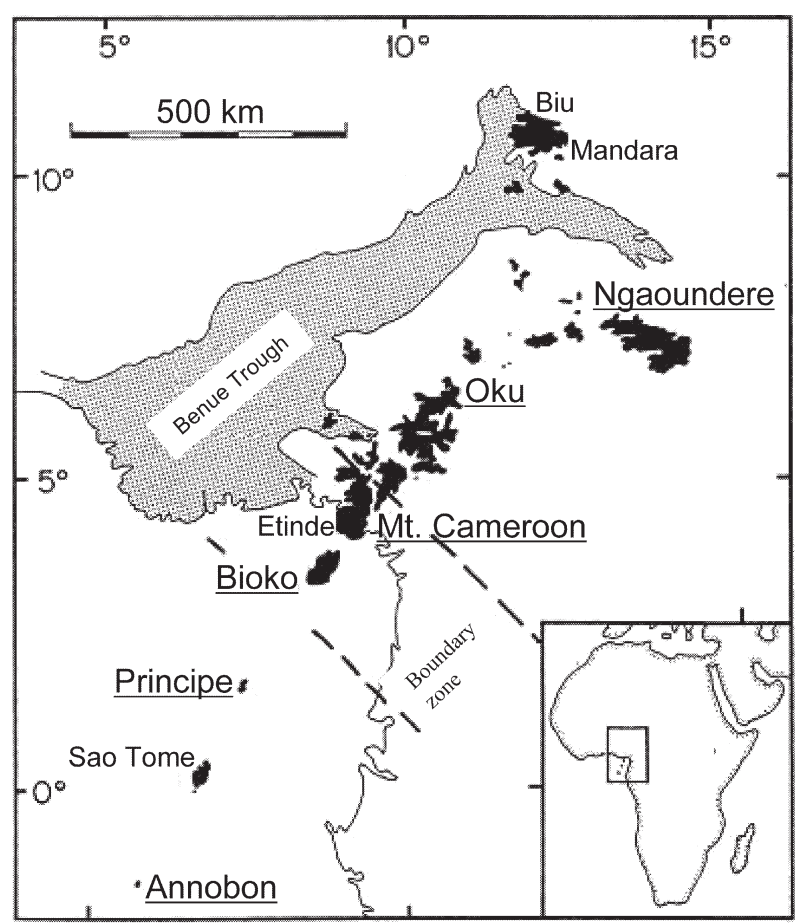

Figure 1. Location map of the Cameroon volcanic line modified after Halliday et al. (1990). The black area shows the distribution of the Cenozoic volcanic centers. The peridotite xenoliths examined in this study were taken from the underlined locations.

active (Fitton et al., 1983).

The Benue Trough is filled with sediments, and there are no extensively developed outcrops of volcanic rocks (e.g., Fitton, 1980). However, volcanic rocks underlying the earliest Albian $(\sim 108 \mathrm{Ma})$ sediments and a number of small outcrops of lavas and tuffs among the Cretaceous are observed in the Benue valley (Uzuakpunwa, 1974; Olade, 1978; Fitton, 1980). These volcanic rocks have alkaline affinities and are known to have erupted during the development of the Benue Trough (Olade, 1978). Moreover, a positive gravity anomaly in the Benue Trough (e.g., Poudjom-Djomani et al., 1995) suggests the existence of dense materials such as plutonic rocks under this area. Consequently, igneous activity by the emplacement of a plume is considered to have occurred beneath the Benue Trough.

Fitton (1980) pointed out the remarkable shape and size similarities between the CVL and Benue Trough. As shown in Figure 1, the CVL extends northeast from the Atlantic island of Annobon (Pagalu). North of Oku, in the continental region, the CVL splits into a two-branches in a Y-shape. One branch runs northward to the Biu Plateau while the other runs eastward through the Ngaoundere Plateau. The Benue Trough also splits into two branches at its northeastern end. If the CVL were rotated by $7^{\circ}$ about a pole at $12.2^{\circ} \mathrm{N}, 30.2^{\circ} \mathrm{E}$ relative to the Benue 
Trough, then the former would be superimposed on the latter. Fitton (1980) considered that this geometrical coincidence resulted from a displacement of the African lithosphere relative to its underlying asthenosphere (i.e., hot zone). He estimated that the rotation of Africa occurred between 80 and $70 \mathrm{Ma}$ based on the long-life hot spot trails, such as Walvis Ridge (Tristan da Cunha and Gough) in the Atlantic Ocean (e.g., Fitton, 1980, 1983; O'Connor and le Roex, 1992).

The complex structure of this area was explained in terms of the following three stages (e.g., Fitton 1980). (1) At about $120 \mathrm{Ma}$, the Benue Trough was formed by the rifting of the RRR triple junction resulting from the mantle plume emplacement. (2) At 80-70 Ma, the rotation of Africa took place. At this stage, the asthenosphere beneath the Benue Trough was displaced relative to the lithosphere, and moved to a new position beneath Cameroon and the Gulf of Guinea. (3) At 37 Ma-present, the Cameroon volcanic line formed in the region of Cameroon and the Gulf of Guinea. During these three stages, the mantle plume (i.e., hot zone) has continued to move away from the Benue Trough toward St. Helena in the Atlantic Ocean (O'Connor and le Roex, 1992). At the beginning of the Cameroon volcanism $(\sim 37 \mathrm{Ma})$, the plume was located at a great distance (more than $2000 \mathrm{~km}$ ) from the Cameroon area. Therefore, this plume was probably not a heat source for the volcanism of the Cameroon line, as discussed below.

The ultramafic xenoliths, derived from the upper mantle in a wide area from Annobon Island to the Ngaoundere Plateau, were carried by the magmas of the CVL. In this study, we obtained peridotite xenoliths from three oceanic volcanoes: Annobon, Principe, and Bioko, and three continental volcanoes: Mt. Cameroon, Oku, and Ngaoundere (Fig. 1).

\section{PETROGRAPHY}

Table 1 (available online from http://www.jstage.jst.go.jp/ browse/jmps) lists the rock types, textures, and modal compositions of all the studied samples, which included 11 ultramafic xenoliths from Pagalu (Annobon), 2 from Principe, 23 from Bioko, 7 from Mt. Cameroon, 34 from Oku, and 13 from Ngaoundere. The most abundant rock types of the ultramafic xenoliths are spinel lherzolite and spinel harzburgite, with subordinate amounts of dunite, wehrlite, websterite, and orthopyroxenite. We observed that the host basaltic magma rarely infiltrated into the grain boundaries of the minerals in peridotite xenoliths.

The lherzolite and harzburgite shows coarse granular or coarse tabular to weakly porphyroclastic textures (Boullier and Nicolas, 1973) (Fig. 2). They are mainly composed of olivine, orthopyroxene (opx), clinopyroxene (cpx), and chromian spinel. The modal composition of the xenoliths varies from lherzolitic to harzburgitic (Fig. 3). In this study, the cpx/(opx $+\mathrm{cpx})$ volume ration of 0.1 was set as a boundary between harzburgite and lherzolite (Arai, 1984) (Fig. 3). The lherzolite consists of 43-91 vol $\%$ olivine, $6-39 \mathrm{vol} \%$ opx, $1-23 \mathrm{vol} \% \mathrm{cpx}$, and $0-6$ vol $\%$ spinel. The harzburgite consists of 5-93 vol $\%$ olivine, 6-43 vol\% opx, 0-2\% cpx, and $0.3-2$ vol $\%$ spinel. The olivine, opx, and cpx crystals are usually kinked or show wave distinction. The opx sometimes has exsolution lamellae of cpx. Thin chromian spinel lamellas rarely occur in the opx (Fig. 2). The cpx also has exsolution lamellae of opx and spinel. Some of the pyroxenes and olivine have fine fluid inclusions. The spinel is anhedral and rarely vermicular and shows symplectitic texture (Fig. 2d). The color of the spinel varies in thin section, from pale brown to brownish in lherzolite and brown to dark red in harzburgite.

We observed regional variations in the petrography of the lherzolite and harzburgite. In Bioko, which is an oceanic island close to the continental margin of Africa (see Fig. 1), harzburgite is the most dominant rock type, though it is rare in other areas. In Bioko and Principe, chromian spinel rarely forms symplectite texture with clinopyroxene and orthopyroxene (Table 1 and Fig. 2). In continental areas, such as Mt. Cameroon, Oku, and Ngaoundere, lherzolite is more abundant and rarely contains small amounts of amphibole (pargasite).

Dunite and wehrlite are abundant in Bioko. In this study, dunite is defined as having an olivine/(olivine + opx + cpx) volume ratio $\geq 0.95$ (Fig. 3 ). We found two different mineral assemblies of dunite (Table 1). The first is composed of olivine and small amounts of cpx and chromian spinel, and licks opx. The second includes opx in addition to the mineral assemblage of the first type, but is similar to harzburgite from the point of view of its mineral assemblage and texture. The chromian spinel is anhedral and opaque in color in thin section. The olivine has kinkband and wave extinction, with coarse granular to porphyroclastic texture. The texture of the wehrlite is similar to that of the opx-free dunite.

Small amounts of pyroxenite (websterite and orthopyroxenite) xenoliths were obtained at Annobon, Oku, and Bioko (Table 1). In Annobon, the websterite mainly consists of $73-86 \mathrm{vol} \%$ opx, $12-27 \mathrm{vol} \% \mathrm{cpx}, 0-1.6 \mathrm{vol} \%$ olivine, and small amounts of ilmenite and rutile. In Oku, a vein of websterite with a thickness of approximately 1 $\mathrm{cm}$ occurs in a large lherzolite xenolith. In the websterite from Annobon and Oku, the opx exhibits exsolution lamellae of cpx and spinel, and the minerals have kinkband and show wave extinction. In Bioko, orthopyroxenite oc- 

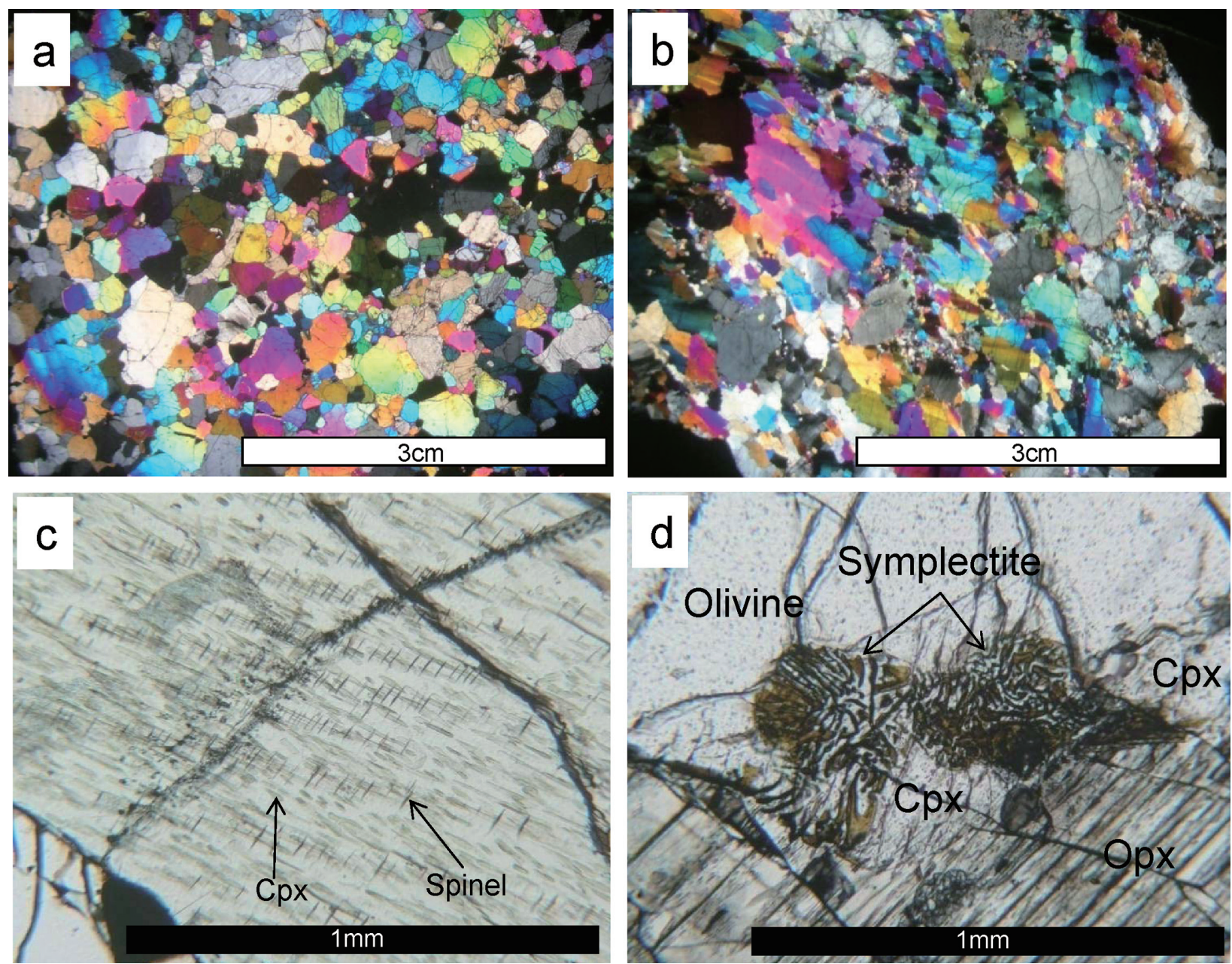

Figure 2. Photomicrographs of peridotite xenoliths from the Cameroon volcanic line. (a) Coarse granular texture of lherzolite in Oku (CA021-2), using cross-polarized light. (b) Coarse tabular to weakly porphyroclastic texture of harzburgite in Bioko (BK019 a-6). Olivine, orthopyroxene, and clinopyroxene crystals are highly deformed and show kinkbands and wavey extinction, using cross-polarized light. (c) Thin chromian spinel and clinopyroxene lamella in orthopyroxene of lherzolite in Annobon (AN01 A-1). Spinel and clinopyroxene show pale brown and gray colors, respectively, using plane-polarized light. (d) Two-pyroxene-spinel symplectite of lherzolite in Bioko (BK07-1). Symplectite texture is mainly observed in the Bioko area, using plane-polarized light.

curs in the dunite and lherzolite as a network of thin veins a few millimeters thick.

\section{MINERAL CHEMISTRY}

Minerals were analyzed using a scanning electron microprobe analyzer (JEOL-JSM5600LV) with an energy-dispersive spectrometer (Oxford) at Ibaraki University under a $15 \mathrm{kV}$ acceleration voltage, a $1 \times 10^{-8} \mathrm{~A}$ beam current, integration counting time of 100 seconds, and working distance of $15 \mathrm{~mm}$ with ZAF correction. All of the Fe in the silicate was assumed to be $\mathrm{Fe}^{2+}$. The cation ratios of the $\mathrm{Fe}^{2+}$ and $\mathrm{Fe}^{3+}$ in the spinel were calculated by assuming spinel stoichiometry. The analytical data are shown in Table 2 (available online from http://www.jstage.jst.go.jp/ browse/jmps). The peridotite xenoliths that are infiltrated into grain boundaries by host magma sometimes show scattered chemical compositions such as $\mathrm{Mg} /(\mathrm{Mg}+\mathrm{Fe})$ atomic ratio. The purpose of this study is to understand the mantle processes before the xenoliths were caught by the host magma. Therefore, we first evaluated the effect of the infiltration of the host basaltic magma under an optical microscope (Table 1). Then, we excluded those samples that showed evidence of reaction with the host basalt, in order to consider just the mantle processes.

Figure 4 shows the relationship between the Fo content $\left[=100 \times \mathrm{Mg} /\left(\mathrm{Mg}+\mathrm{Fe}^{2+}\right)\right.$ atomic ratio $]$ of olivine and the $\mathrm{Cr} \#(\mathrm{sp})[=\mathrm{Cr} /(\mathrm{Cr}+\mathrm{Al})$ atomic ratio $]$ of coexisting chromian spinel. The Fo content ranges from 88 to 91.5 in the lherzolite, and from 90 to 92 in the harzburgite. The $\mathrm{Cr} \#(\mathrm{sp})$ has a positive correlation with the Fo content of coexisting olivine (Fig. 4), and varies greatly depending 

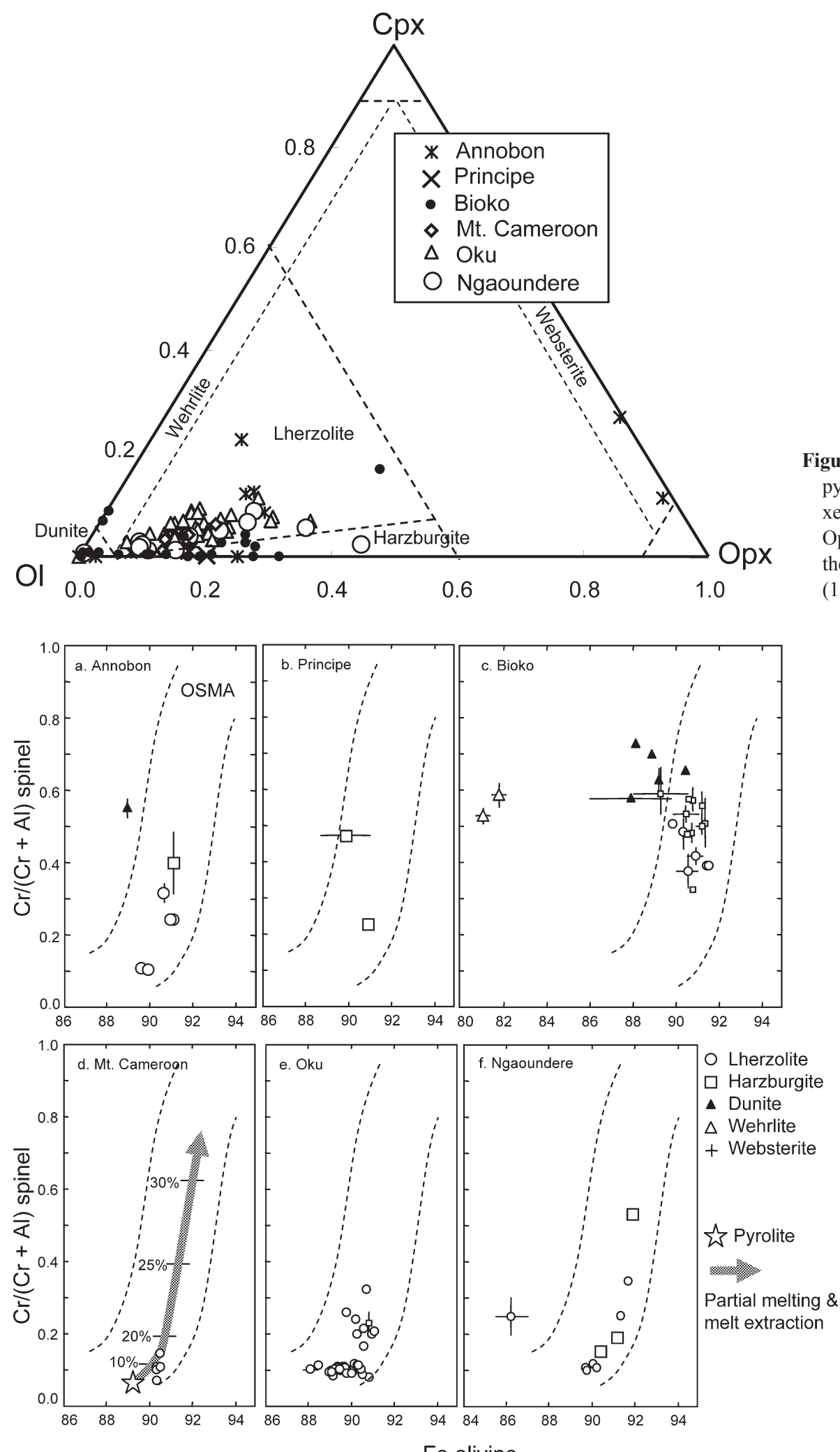

Figure 3. Volume proportion of olivine, orthopyroxene, and clinopyroxene of ultramafic xenoliths. Ol, olivine; Cpx, clinopyroxene; Opx, orthopyroxene. The boundary between the lherzolite and harzburgite is after Arai (1984).
Figure 4. Relationships of Fo content $\left[=100 \times \mathrm{Mg} /\left(\mathrm{Mg}+\mathrm{Fe}^{2+}\right)\right.$ atomic ratio] of olivine and $\mathrm{Cr} /(\mathrm{Cr}+\mathrm{Al})$ atomic ratio of chromian spinel in xenoliths. The OSMA, olivine-spinel mantle array, which was proposed by Arai (1987) as a residual trend of spinel peridotite mantle. The gray thick arrow in Figure 3d shows the depletion trend of residue by partial melting and a melt extraction process of pyrolitic lherzolite at spinel stability field. The numbers indicate the degree of partial melting by batch melting (Ozawa, 1997). on the lithology, from 0.05 to 0.45 in the lherzolite and from 0.15 to 0.60 in the harzburgite. In the lherzolite and harzburgite, the $\mathrm{Cr} \#(\mathrm{sp})$ increases with a decrease in the $\mathrm{cpx} /(\mathrm{cpx}+\mathrm{opx})$ volume ratio (Fig. 5). The Fo content and
$\mathrm{Cr}$ (sp) relation of the lherzolite and harzburgite in the CVL xenoliths agree well with the olivine-spinel mantle array (= OSMA, Arai, 1987; 1994), which shows a residual trend of partial melting and melt extraction processes 


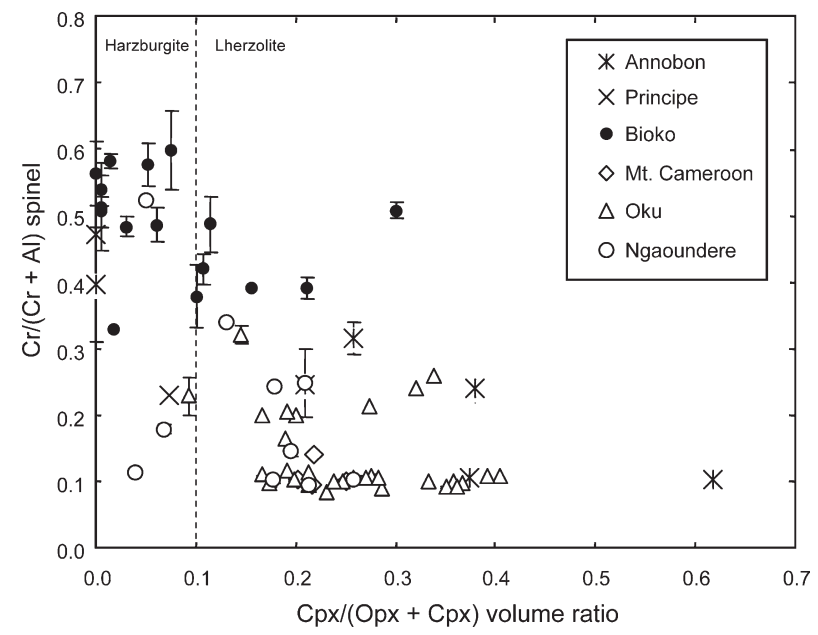

Figure 5. Relationship between the clinopyroxene/(clinopyroxene + orthopyroxene) volume ratio and $\mathrm{Cr} /(\mathrm{Cr}+\mathrm{Al})$ atomic ratio of chromian spinel in lherzolite and harzburgite. Cpx, clinopyroxene; Opx, orthopyroxene.

in the spinel peridotite stability field (Arai, 1994; Ozawa, 1997) (Fig. 4).

The $\mathrm{Cr} \#(\mathrm{sp})$ also has good correlations with the chemistry of the coexisting silicate and oxide minerals. In the orthopyroxene and clinopyroxene, the $\mathrm{Al}$ and $\mathrm{Na}$ contents decrease and the $\mathrm{Mg} \#[=\mathrm{Mg} /(\mathrm{Mg}+\mathrm{Fe})$ atomic ratio] increases with an increase in the $\mathrm{Cr} \#$ of the coexisting spinel (Fig. 6). The Mg\# of the spinel decreases with an increase in the $\mathrm{Cr} \#(\mathrm{sp})$. The $\mathrm{Mg} \#-\mathrm{Cr} \#$ relation of the spinel also agrees with the residual trend of upper-most mantle peridotites at various tectonic settings (e.g., Matsukage and Kubo, 2003).

In dunite and wehrlite, the constituent minerals (olivine, orthopyroxene, clinopyroxene, and spinel) tend to show smaller Mg\# values than those in the harzburgite (Fig. 7). The $\mathrm{Al}$ and $\mathrm{Na}$ contents of clinopyroxene, and the $\mathrm{Ti}$ and $\mathrm{Fe}^{3+}$ contents of the spinel are higher than those of the harzburgite when compared with the same $\mathrm{Cr} \#$ of coexisting spinel (Table 2). In websterite, the $\mathrm{Fe}$ and $\mathrm{Al}$ contents of the pyroxenes are much higher than those of the dunite and wehrlite.

We observed systematic regional differences in the mineral chemistries, which may be related to the petrography. In lherzolite and harzburgite from Bioko, the incompatible elements in the minerals, such as $\mathrm{Al}_{2} \mathrm{O}_{3}$ and $\mathrm{Na}_{2} \mathrm{O}$, are less concentrated compared to those in other areas. Moreover, the lower limit of the $\mathrm{Cr} \#(\mathrm{sp})$ is higher than that in other areas (Fig. 4). The lowest $\mathrm{Cr} \#(\mathrm{sp})$ is 0.33 (BK07-2) in Bioko, while it is about 0.05-0.1 in other areas.

\section{EQUILIBRIUM TEMPERATURE}

We estimated the equilibrium temperature of the xenoliths with a two-pyroxene geothermometer (Wells, 1977). Two different data sets of clinopyroxene and orthopyroxene were used for this calculation. The first was the average for several pyroxene grains in each rock, and the second was a pair of coarse crystals and its exsolution lamella. The calculated temperatures for the average of several grains and the lamella are consistent with each other (Fig. 8). As shown in Figure 8, the calculated temperatures are highly variable, ranging from $700{ }^{\circ} \mathrm{C}$ to $1200{ }^{\circ} \mathrm{C}$. The average temperatures are the highest in Bioko, Mt. Cameroon, and Oku, and are lower in places such as Annobon and Ngaoundere at the margin of the CVL (Figs. 1 and 8). The difference in the average temperatures between Bioko and Annobon is more than $100^{\circ} \mathrm{C}$.

\section{DISCUSSION AND CONCLUSIONS}

\section{Petrogenesis of peridotite xenoliths in Cameroon vol- canic line}

The trend in the chemical and modal variations in the lherzolite and harzburgite from the CVL is consistent with the theoretical and experimental observations of partial melting in the upper mantle in the spinel stability field (e.g., Quick, 1981; Dick and Bullen, 1984; Arai, 1994; Ozawa, 1997; Matsukage and Kubo, 2003). If pyrolitic lherzolite, which is a hypothetical primitive mantle (Ringwood, 1966), is partially molten in the spinel stability fields $(<2.5 \mathrm{GPa})$, clinopyroxene is preferentially molten relative to olivine and orthopyroxene with increasing temperature or decreasing pressure. The residual rock type changes from lherzolite to harzburgite with an increase in the degree of partial melting and melt extraction. At the same time, the residual rocks are depleted of $\mathrm{SiO}_{2}, \mathrm{Al}_{2} \mathrm{O}_{3}$, and $\mathrm{CaO}$ with respect to $\mathrm{MgO}$ and $\mathrm{Cr}_{2} \mathrm{O}_{3}$. The $\mathrm{Mg} \#$ of silicate minerals and the $\mathrm{Cr} \#$ of spinel are good indicators of depletion, and increase with an increase in the degree of partial melting and melt extraction. The olivine-spinel mantle array (= OSMA) in Figure 4 indicates a residual peridotite trend in terms of the Fo content of olivine and the $\mathrm{Cr} \#$ of spinel during progressive partial melting (Arai, 1987). It is noteworthy that data from the most natural spinel lherzolite and harzburgite from various tectonic settings, such as mid-ocean ridges, arcs, forearcs, and continents, are plotted within OSMA (Arai, 1994). The peridotites from the CVL have been characterized by a wide lithological variation from lherzolite with 23 vol\% of clinopyroxene to harzburgite without clinopyroxene (Fig. 5). The amounts of $\mathrm{Mg}$ and $\mathrm{Cr}$ increase and those of 

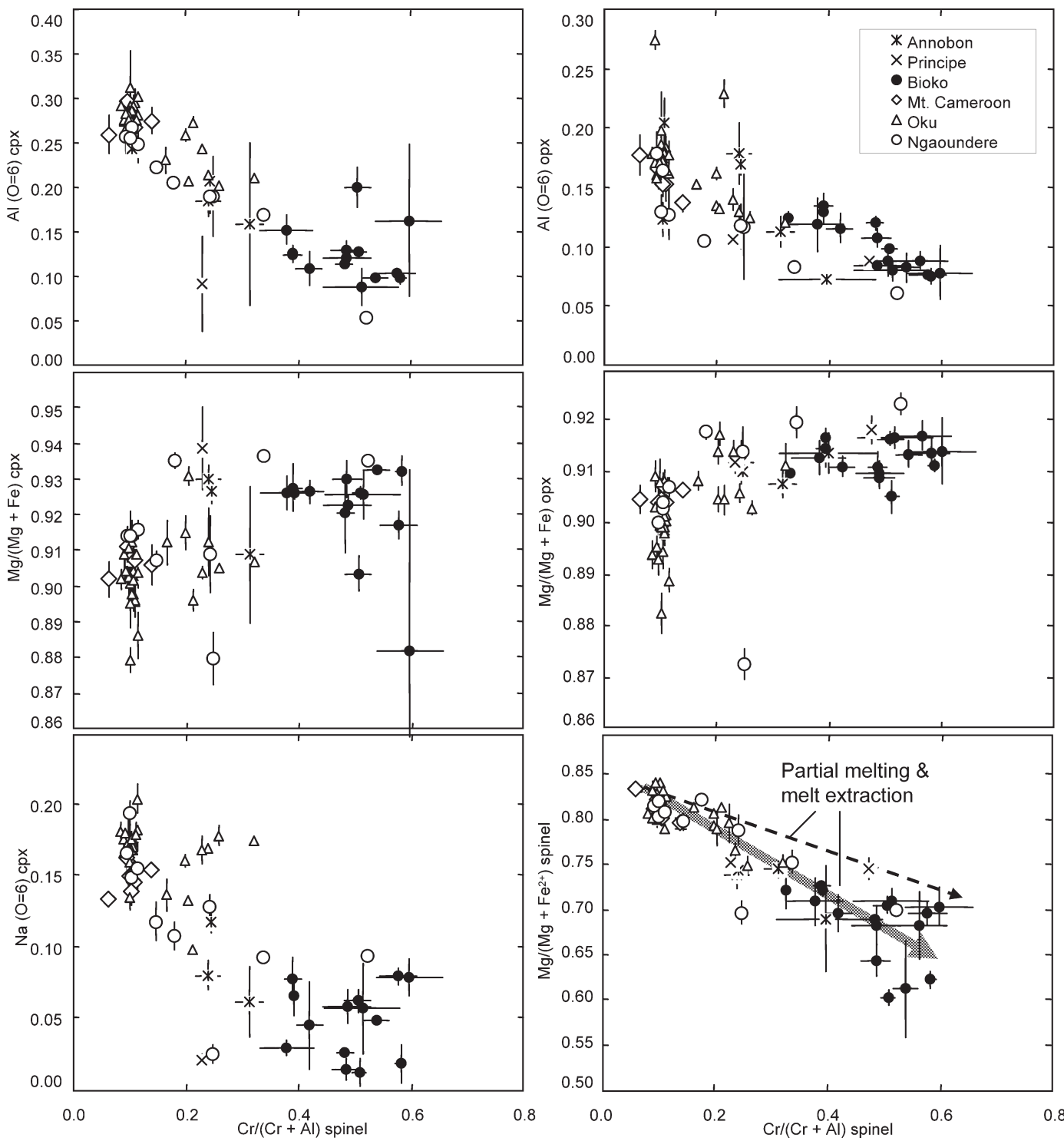

Figure 6. Relationships among $\mathrm{Cr} /(\mathrm{Cr}+\mathrm{Al})$ atomic ratio of chromian spinel and the mineral chemistries of clinopyroxene, orthopyroxene, and chromian spinel in lherzolite and harzburgite. The broken arrow indicates the depletion trend by melting experiments at 1.0-1.5 GPa after Hirose and Kawamoto (1995) and Matsukage and Kubo (2003). The gray thick arrow indicates the trend of natural residual peridotites from mid-ocean ridges (America-Antarctic ridges, Southwest Indian ridges, and East Pacific Rise) after Dich and Bullen (1984), Dick (1989), Arai and Matsukage (1996), and Dick and Natland (1996). Cpx, clinopyroxene; Opx, orthopyroxene.

$\mathrm{Al}$ and $\mathrm{Ca}$ decrease with a decrease in the modal proportion of clinopyroxene (Figs. 4 and 5). These modal and chemical variations in the lherzolite and harzburgite are in good agreement with the results of the theoretical and experimental studies of partial melting and melt extraction processes from the upper mantle, as described above.

Most of the peridotite xenoliths obtained here was considered to have melted in the spinel stability field, because the peridotites do not contain garnet or plagioclase but contain chemically homogeneous coarse chromian spinel. The spinel stability is strongly dependent on pressure (O'Neill, 1981; Gasparik, 1987). Because of this, spinel reacts with pyroxenes to produce garnet and olivine at higher pressure, and produces plagioclase and olivine at lower pressure (Fig. 9). Therefore, the existence of spinel constrains the pressure (= depth) conditions of the peridotite to the upper mantle. In contrast, two-pyroxene spinel symplectite (Fig. 2) occurs in some residual peridotites in Bioko (Table 1). The texture likely suggests that the melting may have started in the garnet stability field, even though the peridotites from the CVL finally equilibrated in the spinel stability field, because the two-pyroxene spinel symplectite indicates former garnet at deeper depths (e.g., Obata, 1980; Takahashi and Arai, 1989). 

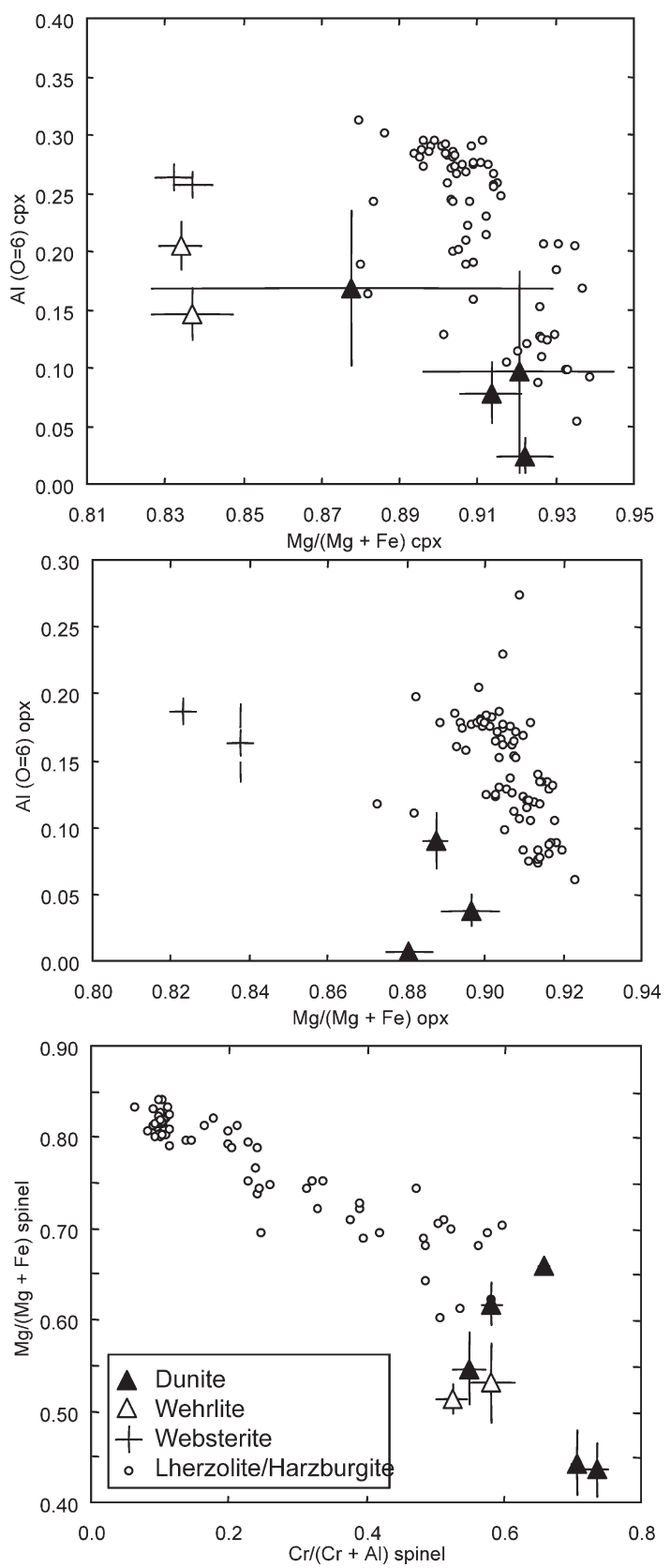

Figure 7. Mineral chemistries of pyroxenes and spinel from dunite, wehrlite, and websterite compared with those from lherzolite and harzburgite. Cpx, clinopyroxene; Opx, orthopyroxene.

The dunite, wehrlite, and websterite of CVL, however, cannot be explained as residues. The higher concentrations of $\mathrm{Al}$ in pyroxenes, and the $\mathrm{Ti}, \mathrm{Fe}^{2+}$, and $\mathrm{Fe}^{3+}$ in spinel relative to the harzburgite (Fig. 7) indicate that the dunite, wehrlite, and websterite of the CVL are cumulates of the early crystallization of mafic magma. The wide chemical variations in the $\mathrm{Mg} \#$ of olivine and pyroxenes in the dunite, wehrlite, and websterite (Figs. 4 and 7) are characteristic of cumulates. In general, the cumulates crystallized from a basaltic melt tend to show low Mg\# compared to coexisting residual peridotites and a steeper trend against the OSMA (e.g., Arai, 1994) because the Mg preferentially distributes to the early crystallized silicate minerals.

In contrast, the $\mathrm{Cr} \#$ of spinel in a cumulate dunite is a good indicator of the chemistry of the host magma. The melt produced by a high degree of partial melting of mantle peridotites can precipitate chromian spinel with high $\mathrm{Cr} \#$ at a shallower area (e.g., Arai, 1994). The CVL dunite and wehrlite have spinel with high $\mathrm{Cr} \#$, from $0.5-0.75$ (Figs. 4 and 7). Such a high Cr\# in spinel is not common in cumulate rocks except for those from forearc and intraplate regions. In forearc and intraplate regions, some of the dunite is considered to be a cumulate of melt produced by an extremely high degree of partial melting of mantle materials because of the fall in the solidus temperature by a hydrous condition and/or extremely high temperature condition (e.g., Tamura et al. 1999). Consequently, the high $\mathrm{Cr} \#$ of spinel in the CVL dunite suggests that the deeper mantle under the CVL experienced an extremely high degree of partial melting.

We observed the systematic spatial variability of the petrography and mineral chemistries. In Bioko, residual peridotites such as lherzolite and harzburgite are clearly more refractory than in other areas (Figs. 4-6). Except for Bioko, most of the lherzolite is similar to pyrolitic primitive mantle in composition, with this composition plotted at a low Fo content and Cr\#(sp) in OSMA (Fig. 4). This means that most of the lherzolite did not experience extensive partial melting. The maximum degree of partial melting in these areas, except for Bioko, was estimated to be less than $25 \%$. On the other hand, the high $\mathrm{Cr} \#$ of the spinel, high $\mathrm{Mg} \#$ of the silicate minerals, and predominance of harzburgite in Bioko indicates that the mantle beneath the Bioko area suffered from extensive partial melting and melt-extraction processes. The estimated degree of partial melting in Bioko was about $25-30 \%$. In other words, extensive igneous activity occurred under the Bioko area.

\section{Relationship between mantle variability and plume upwelling about $120 \mathrm{Ma}$}

Here we discuss the origin of the spatial variability of the petrography and mineral chemistry of the upper-most mantle beneath the CVL. Previous studies on volcanic rocks found the regional isotope variability of the upper mantle beneath the CVL (e.g., Fitton et al., 1983; Halliday et al., 1988; Halliday et al., 1990; Lee et al., 1994; Ballentine et al., 1997). Halliday et al. (1990) studied the isotope chemistry of the young lava (basalt, basanite, nephelinite, and more evolved rocks) from volcanoes in the CVL, and 


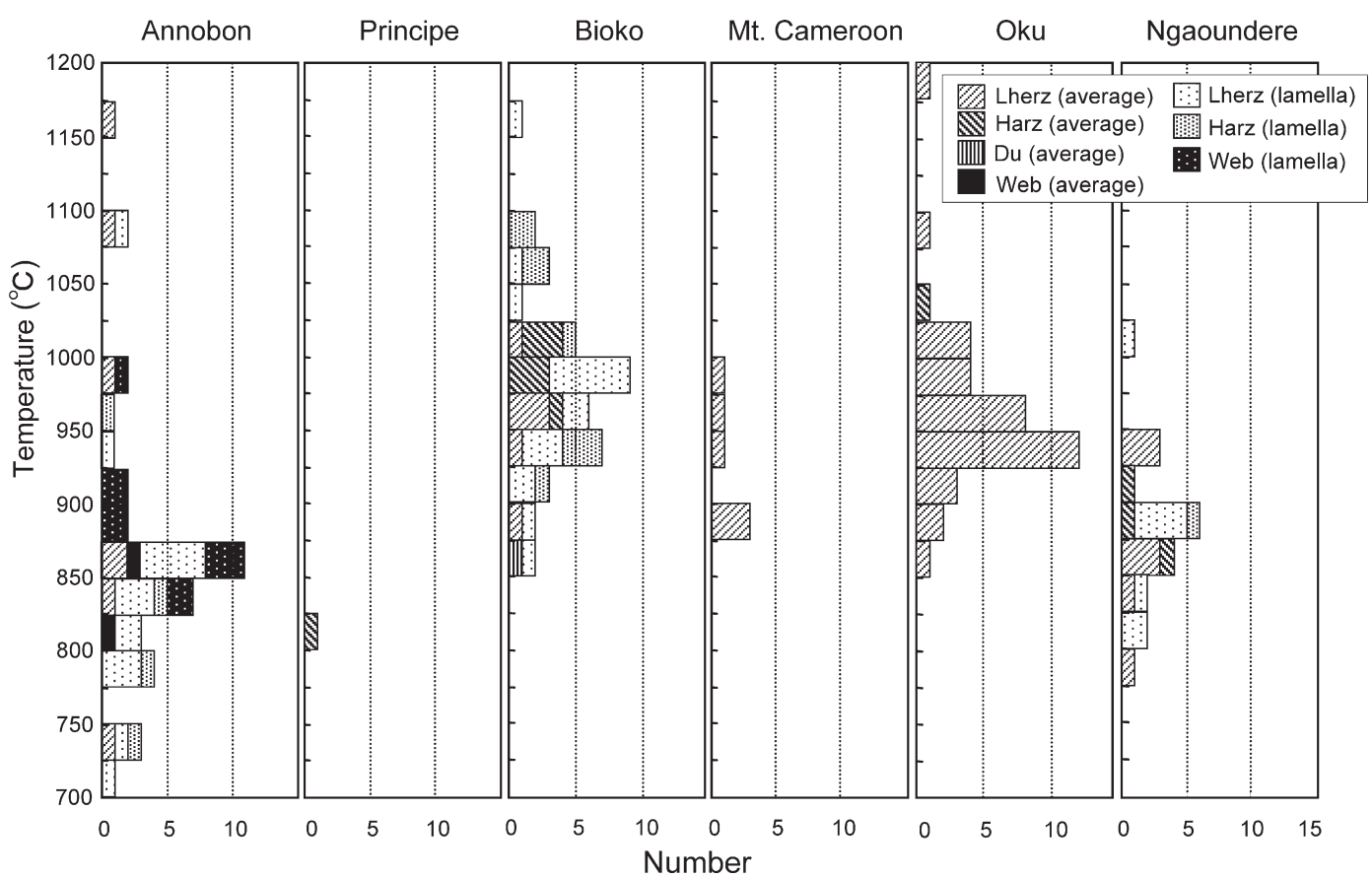

Figure 8. Estimated equilibration temperatures of xenoliths from Cameroon volcanic line. The temperatures were calculated using the two-pyroxene geothermometer of Wells (1977). Lherz, lherzolite; Harz, harzburgite; Du, dunite; Web, websterite.

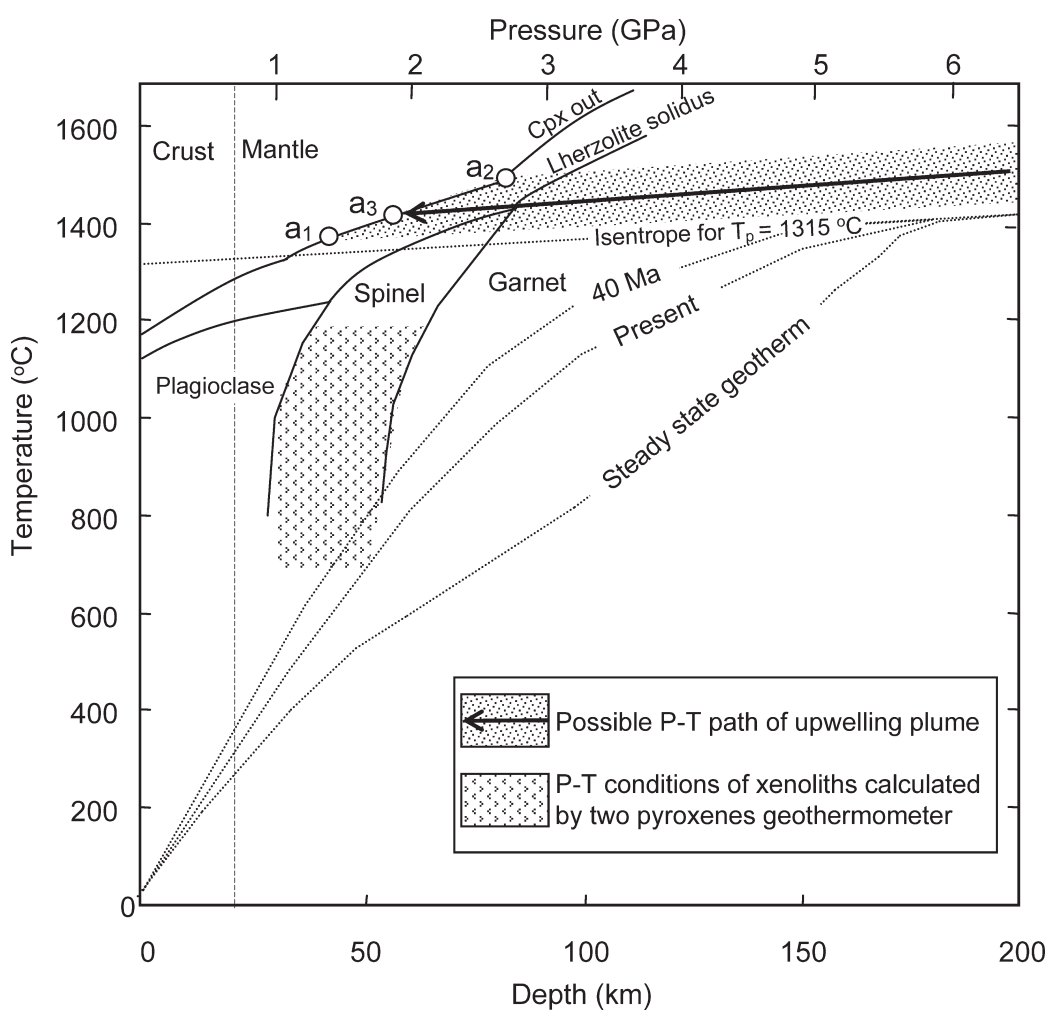

Figure 9. Temperature-pressure condition of xenoliths from Cameroon volcanic line estimated by two-pyroxene geothermometer, and possible temperature-pressure path of an upwelling plume. The solidus and above-solidus phase diagram of pyrolitic lherzolite is after Takahashi and Kushiro (1983), Takahashi et al. (1993), and Matsukage and Kubo (2003). Sub-solidus phase relation of pyrolitic lherzolite is after O'Neill (1981), Gasparik (1987), and Klemme and O'Neill (2000). The isentrope thermal structures for $T_{\mathrm{P}}=1315^{\circ} \mathrm{C}$, thermal structure for $40 \mathrm{Ma}^{-}$ present, and steady state geotherm are after McKenzie et al. (2005). The thickness of the crust under the Cameroon volcanic line is after Poudjom-Djomani et al. (1995); Plagioclase, plagioclase stability field; Spinel, spinel stability field; Garnet, garnet stability field. reported drastic changes in the isotopic compositions in the center of the CVL, close to the continent/ocean boundary (Fig. 1). They observed that the three volcanic centers (Bioko, Etinde, and Mt. Cameroon) close to the continent/ocean boundary were distinctive in radiogenic
$\mathrm{Pb}$ and unradiogenic $\mathrm{Nd}$ for a given $\mathrm{Sr}$ isotopic ratio compared to other volcanic centers, and pointed out that the data were similar to the compositions observed for St. Helena. The isotope composition for St. Helena is known as the HIMU mantle type. They called the region with this 
isotope anomaly a "continent/ocean boundary zone." This HIMU-like $\mathrm{Pb}$ isotope anomaly is most apparent in the three volcanic centers, especially Etinde, with the anomaly gradually decreasing toward both margins of the CVL. Halliday et al. (1990) concluded that an upwelling deep mantle plume emplacement at about $120 \mathrm{Ma}$, which caused the opening of the Atlantic Ocean, formed the isotope heterogeneity of the upper mantle under the CVL.

The petrological and chemical observations of the mantle xenoliths reported in this study are consistent with the inference from the previous isotope studies (Halliday et al., 1990; Lee et al., 1994; Ballentine et al., 1997). The spatial variability of the peridotite xenolithes observed in our study seems to be related to the spatial isotope anomaly found in these previous studies. It seems that the isotope anomaly of young volcanic rocks, the degree of depletion of the residual mantle, and the amount of cumulus rocks are the highest at the center of the CVL and gradually decrease toward both margins. Based on this circumstantial evidence, we speculate that the spatial variability of the petrography, mineral chemistry, and isotope chemistry of the upper-most mantle beneath the CVL originated from a single event: the heating of the lithospheric mantle by an emplacement of hot mantle plume at about $120 \mathrm{Ma}$.

Based on the "rotation model of Africa" by Fitton $(1980,1983)$, we conclude that the inferred upwelling of a deep mantle plume at about 120 Ma may be responsible for the petrological and chemical variability of the upper mantle under the "Benue Trough." At the time of the rotation event in Africa about $80 \mathrm{Ma}$, the petrologically and chemically heterogeneous hot mantle was possibly displaced to the new position beneath Cameroon. Most of the residual peridotites beneath the CVL are considered to represent the heating of the lithospheric mantle by a rising mantle plume because there is no evidence of decompression from a deeper depth, even though a few fragments of mantle plume that may have been emplaced in the bottom of the lithospheric mantle are obtained as xenoliths. The symplectite bearing residual peridotite xenoliths may be the fragments of such an upwelling mantle plume because the two-pyroxene spinel symplectite texture suggests a decompression reaction (Obata, 1980; O'Neill, 1981; Takahashi and Arai, 1989). Moreover, some of the dunite and wehrlite xenoliths can be considered to be the early cumulate from the melt, which formed by the partial melting of plume materials. A plume origin for cumulus rocks is supposed because an extremely high degree of partial melting at high temperatures is suggested by the variation in the mineral chemistry of the cumulus rocks in the CVL. The most plausible heat source for this extremely high degree of partial melting is the emplacement of a mantle plume at $\sim 120 \mathrm{Ma}$ in this area.

The center of the CVL (e.g., Bioko) recorded the greatest degree of partial melting, and the existence of a large amount of cumulus rocks. These observations suggest that the center of the CVL mantle was hotter than the margin when the plume rose to the overlying lithospheric mantle. In other words, after the displacement at $\sim 80 \mathrm{Ma}$, the center of a "fossil plume head" might have existed at the center of the CVL. Halliday et al. (1990) also reached the same conclusion based on the spatial variability of the mean ${ }^{206} \mathrm{~Pb} /{ }^{204} \mathrm{~Pb}$ ratio of young lavas.

\section{Estimation of the temperature of an upwelling mantle plume}

If the existence of residual harzburgite in Bioko was the result of heating by a hot plume placed under the boundary of Africa and South America about $120 \mathrm{Ma}$, the petrography and mineral chemistry of the present mantle xenoliths may constrain the $P-T$ condition(s) of the upwelling mantle plume. As discussed above, the maximum degree of partial melting estimated from the harzburgite in Bioko is about $30 \%$, which is close to the conditions needed for the disappearing of clinopyroxene. Since partial melting is considered to occur at $P-T$ conditions in the spinel stability field based on petrographical observations, the $P-T$ path of an upwelling plume needs to cross the "cpx-out" curve at the pressure conditions for spinel stability (1.1 GPa $\leq \mathrm{P} \leq 2.5 \mathrm{GPa})$. We estimate that the temperature of a mantle plume passes $1375^{\circ} \mathrm{C}$ at $1.1 \mathrm{GPa}\left(\mathrm{a}_{1}\right.$ in Fig. 9) for the coldest case and $1470{ }^{\circ} \mathrm{C}$ at $2.5 \mathrm{GPa}\left(\mathrm{a}_{2}\right.$ in Fig. 9) for the hottest case when the plume is emplaced at the bottom of the lithosphere. Based on the $P-T$ conditions of $a_{1}$ and $a_{2}$ in Figure 9, we calculated the possible $P-T$ path of an upwelling mantle plume (dotted area in Fig. 9). This calculation was carried out on the assumption that the plume rises by the adiabatic decompression process. Figure 9 also shows an isentrope geotherm that has the thermal structure with the ability to form normal MORB (potential temperature, $T_{\mathrm{p}}=1315^{\circ} \mathrm{C}$ ) (McKenzie et al., 2005). As shown in Figure 9, the $P-T$ path of an upwelling plume is higher than the normal isentrope geotherm. The difference between the isentrope geotherm and the plume temperature is estimated to be about $50-140$ ${ }^{\circ} \mathrm{C}$.

\section{Is the spatial variability of equilibrium temperature at 0-40 Ma a plume fossil?}

We found the spatial thermal variability beneath the Cameroon volcanic line. The equilibrium temperatures of xenoliths calculated by the two-pyroxene geothermometer 


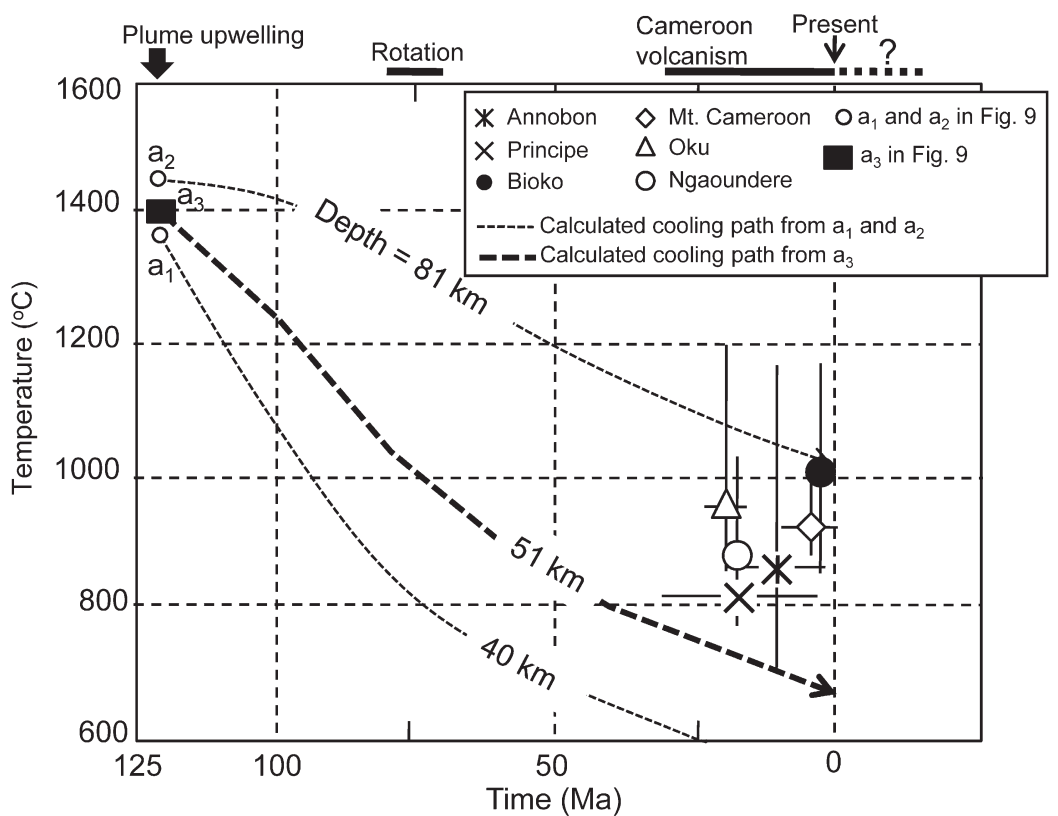

Figure 10. The equilibrium temperatures of the xenoliths from the Cameroon volcanic line plotted as a function of the eruption time of the host volcanics. The data for the $\mathrm{K}-\mathrm{Ar}$ ages of the host volcanic rocks are after Fitton and Dunlop (1985). The cooling paths of $\mathrm{a}_{1}, \mathrm{a}_{2}$, and $\mathrm{a}_{3}$ were calculated using a half-space cooling model (see text). are higher than the theoretical normal geotherm (see curves for $40 \mathrm{Ma}$ and present in Fig. 9) estimated from the potential temperature for normal MORB $\left(T_{\mathrm{p}}=1315\right.$ $\left.{ }^{\circ} \mathrm{C}\right)$ (McKenzie et al., 2005). The equilibrium temperature is considered to be the temperature recorded at the time of eruption of the young magmas with mantle xenoliths from the Tertiary $(\sim 40 \mathrm{Ma})$ to the present (e.g., Fitton and Dunlop, 1985). If the RRR triple junction rift developed along a normal geotherm (the isentrope thermal structure in Fig. 9; McKenzie et al., 2005) at $120 \mathrm{Ma}$, the mantle xenoliths carried by young magmas should have temperatures along the geotherms of $40 \mathrm{Ma}$-present in Figure 9. Most of the xenoliths, however, record higher temperatures (Figs. 8 and 9), especially in the center of the CVL. This observation supports the hypothesis that all of the systematic spatial variability of the petrology, mineral chemistry, isotope chemistry, and thermal anomaly of the mantle observed at the CVL originated from the emplacement of a single hot mantle plume at $120 \mathrm{Ma}$. If this hypothesis is correct, we can assume that the thermal variation at $0-40 \mathrm{Ma}$ is a remnant of the heat from the mantle plume at $120 \mathrm{Ma}$.

To evaluate this hypothesis, we calculated the cooling path of the lithosphere that had been heated by the mantle plume at $\sim 120$ Ma by using a half-space cooling model. Calculations were performed at the three $P-T$ conditions, $a_{1}, a_{2}$, and $a_{3}$, in Figure 9. $a_{3}$ is the intersection of a line depicting the average $P-T$ paths of possible upwelling mantle plumes with the curve of the phase boundary between clinopyroxene-bearing and clinopyroxene-free peridotite. The thermal diffusivity is assumed to be $7.8 \times$ $10^{-7} \mathrm{~m}^{2} / \mathrm{s}$ (Seno, 2001). Figure 10 compares the cooling paths and the equilibrium temperatures of mantle xenoliths as a function of time. Because most of the lherzolite was caught by host magmas in the spinel stability field (see above the first paragraph of "discussion and conclusion"), the equilibrium temperature of the lherzolite of the CVL should be plotted on the theoretical temperaturetime trend of the depth of less than $50 \mathrm{~km}$ (Fig. 9) if this hypothesis is correct. The equilibrium temperatures of Cameroon xenoliths, however, fall off from the theoretically calculated temperature-time trend at the depth of 40-51 km (Fig. 10). The equilibrium temperatures beneath the CVL are higher than the temperatures at the depth of $40-50 \mathrm{~km}$. The difference is very large, i.e., it is about $300{ }^{\circ} \mathrm{C}$ in the Bioko area (Fig. 10). The higher equilibrium temperatures from the latter period beneath the CVL suggest that another heat source may have supplied the CVL area after the plate with the CVL moved away from the upwelling position of the deep mantle plume at about $120 \mathrm{Ma}$. The recent gravity and seismic data suggest the thinning and weakening of the lithosphere underlying the CVL (e.g., Browne and Fairhead, 1983; Poudjom-Djomani et al., 1995, 1997; Begg et al., 2009). The zone of this thinning and weakening of the lithosphere seems to elongate from the CVL to the Central African Shear Zone and Sudan rift (e.g., Fairhead and Binks, 1991; Poudjom-Djomani et al., 1997; Begg et al., 2009). Poudjom-Djomani et al. (1997) interpreted the Cameroon volcanic line as probably being in a very early stage of continental rifting from Central Africa. The Cameroon volcanism is likely the product of a combination of chemical modification by the plume at about $120 \mathrm{Ma}$ and lithosphere thinning by Central African rifting at present. The 
thermal anomaly obtained in our study of mantle xenoliths is consistent with the model from the geophysical studies.

\section{ACKNOWLEDGMENTS}

The authors thank M. Kusakabe and A.F. Tongwa for providing us with peridotite xenolith samples, M. Tagiri and A. Fujinawa for discussions on the petrology, and T. Noguchi for advisement with SEM-EDS measurements of mineral chemistry. We also thank Y. Nishihara and S. Whitaker for their reading of a draft of this manuscript. The comments by M. Obata, E. Takazawa, and an anonymous reviewer are also appreciated.

\section{DEPOSITORY MATERIALS}

Tables 1 and 2 are available online from http://www.jstage. jst.go.jp/browse/jmps.

\section{REFERENCES}

Abe, N., Arai, S. and Yurimoto, H. (1998) Geochemical characteristics of the upper mantle beneath the Japan island arcs: implications for upper mantle evolution. Physics of the Earth and Planetary Interiors, 107, 233-248.

Arai, S. (1984) Igneous mineral equilibria in some alpine-type peridotites in Japan. In Materials science of the Earth's interior (Sunagawa, I. Ed.). Terra Scientific publishing Co., Tokyo, 445-460.

Arai, S. (1987) An estimation of the least depleted spinel peridotite on the basis of olivine-spinel mantle array. Neues Jahrbuch für Mineralogie Monatshefte, 8, 347-354.

Arai, S., (1994) Characterization of spinel peridotites by olivinespinel compositional relationships: review and interpretation. Chemical Geology, 113, 191-204.

Arai, S. and Matsukage, K. (1996) Petrology of the gabbro-troctolite-peridotite complex from Hess Deep, equatorial Pacific: implications for mantle-melt interaction within the oceanic lithosphere. Proceedings of the Ocean Drilling Program, Scientific Results, 147, 135-155.

Arai, S. and Kida, M. (2000) Origin of fine-grained peridotite xenoliths from Iraya volcano of Batan Island, Philippines: deserpentinization or metasomatism at the wedge mantle beneath an incipient arc? The Island Arc, 9, 458-471.

Ballentine, C.J., Lee, D.-C. and Halliday, A.N. (1997) Hafnium isotopic studies of the Cameroon line and new HIMU paradoxes. Chemical Geoligy, 139, 111-124.

Begg, G.C., Griffin, W.L., Natapov, L.M., O’Reilly, S.Y., Grand, S.P., O’Neill, C.J., Hronsky, J.M.A., Poudjom-Djomani, Y., Swain, C.J., Deen, T. and Bowden, P. (2009) The lithospheric architecture of Africa: Siesmic tomography, mantle petrology, and tectonic evolution. Geosphere, 5, 23-50.

Boullier, A.M. and Nicolas, A. (1973) Classification of texture and fabrics of peridotite xenoliths from South African kimberlites. In Physics and Chemistry of the Earth 9, (Ahrens, L.H., Dawson, J.B., Duncan, A.R. and Eank, A.J. Eds.). Pergaman Press, 467-475.
Browne, S.E. and Fairhead, J.D. (1983) Gravity study of the Central African Rift system: a model of continental disruption 1. the Ngaoundere and Abu Gabra rifts. Tectonophysics, 94, 187-203.

Burke, K., Dessauvagie, T,F.J., and Whiteman, A.J. (1971) Opening of the Gulf of Guinea and geological history of the Benue Depression and Niger delta. Nature Physical Science, 233, 51-55.

Burke, K. and Dewey, J.F. (1973) Plume-generated triple junctions: key indicators in applying plate tectonics to old rocks. Journal of Geology, 81, 406-443.

Dick, H.J.B. (1989) Abyssal peridotite, very slow spreading ridges and ocean ridge magmatism. In Magmatism in the Ocean Basins (Saunders, A.D. and Norry, M.J. Eds.). Geological Society, London, Special Publication, 42, 71-105.

Dick, H.J.B. and Bullen, T. (1984) Chromian spinel as a petrogenetic indicator in abyssal and alpine-type peridotites and spatially associated lavas. Contributions to Mineralogy and Petrology, 86, 54-76.

Dick, H.J.B. and Natland, J.H. (1996) Late-stage melt evolution and transport in the shallow mantle beneath the East Pacific Rise. Proceedings of the Ocean Drilling Program, 147, 103134.

Fairhead, J.D. and Binks, R.M. (1991) Differential opening of the central and south Atrantic Oceans and the opening of the West African rift system. Tectonophysics, 187, 191-203.

Fitton, J.G. (1980) The Benue trough and Caneroon line - a migrating rift system in west Africa. Earth and Planetary Science Letter, 51, 132-138.

Fitton, J.G. (1983) Active versus passive continental rifting: evidence from the West African rift system. Tectonophysics, 94, 473-481.

Fitton, J.G., Kilburn, C.R.J., Thirlwall, M.F. and Hughes, D.J. (1983) 1982 eruption of Mt. Cameroon, West Africa. Nature, 306, 327-332.

Fitton, J.G. and Dunlop, H.M. (1985) The Cameloon line, West Africa, and its bearing on the origin of oceanic and continental alkali basalt. Earth and Planetary Science Letters, 72, 23-38.

Gasparik, T. (1987) Orthopyroxene thermobarometry in simple and complex systems. Contribution to Mineralogy and Petrology, 96, 357-370.

Halliday, A.N., Dickin, A.P., Fallick, A.E. and Fitton, J.G. (1988) Mantle dynamics: a $\mathrm{Nd}, \mathrm{Sr}, \mathrm{Pb}$ and $\mathrm{O}$ isotopic study of the Cameroon line volcanic chain. Journal of Petrology, 29, 181211.

Halliday, A.N., Davidson, J.P., Holden, P., Dewolf, C., Lee, D.-C. and Fitton, J.G. (1990) Trace-element fractionation in plumes and the origin of HIMU mantle beneath the Cameroon line. Nature, 347, 523-528.

Hirose, K. and Kawamoto, T. (1995) Hydrous partial melting of lherzolite at $1 \mathrm{GPa}$ : the effect of $\mathrm{H}_{2} \mathrm{O}$ on the genesis of basaltic magmas. Earth and Planetary Science Letters, 133, 463-473.

Klemme, S. and O'Neill H. StC. (2000) The near-solidus transition from garnet lherzolite to spinel lherzolite. Contribution to Mineralogy and Petrology, 138, 237-248.

Lee, D.-C., Halliday, A.N., Fitton, J.G. and Poli, G. (1994) Isotopic variations with distance and time in the volcanic islands of the Cameroon line: evidence for a mantle plume origin. Earth and Planetary Science Letters, 123, 119-138.

Lee, D.-C., Halliday, A.N., Davies, G.R., Essene, E.J., Fitton, J.G. 
and Temdjim, R. (1996) Melt enrichment of shallow depleted mantle: a detailed petrological, trace element and isotopic study of mantle-derived xenoliths and megacrysts from Cameroon Line. Journal of Petrology, 37, 415-441.

Marzoli, A., Piccirillo, E.M., Renne, P.R., Bellieni, G., Iacumin, M., Nyobe, J.B. and Tongwa, A.T. (2000) The cameroonvolcanic line revisited: Petrogenesis of Continental basaltic magmas from lithospheric and Asthenospheric mantle soutce. Journal of Petrology, 41, 87-109.

McKenzie, D., Jackson, J. and Priestley K. (2005) Thermal structure of oceanic and continental lithosphere. Earth and Planetary Science Letters, 233, 337-349.

Matsukage, K.N. and Kubo, K. (2003) Chromian spinel during melting experiments of dry peridotite (KLB-1) at 1.0-2.5 GPa. American Mineralogist, 88, 1271-1278.

Morgan, J.W. (1983) Hotspot tracks and the early rifting of the Atlantic. Tectonophysics, 94, 123-139.

Nixon, P. H. (1987) Mantle xenoliths. pp864, John Wiley and Sons Ltd.

Obata, M. (1980) The Ronda peridotite: garnet-, spinel-, and plagioclase-lherzolite facies and the $\mathrm{P}-\mathrm{T}$ trajectories of a hightemperature mantle intrusion. Journal of Geology, 21, 533572.

O'Connor, J.M. and le Roex, A.P. (1992) South Atlantic hot spotplume systems: 1. Distribution of volcanism in time and space. Earth and Planetary Science letters, 113, 343-364.

Olade, M.A. (1978) Early Cretaceous basalt volcanism and initial continental rifting in Benue trough, Nigeria. Nature, 273, 458-459.

O'Neill, H. StC. (1981) The transition between spinel lherzolite and garnet lherzolite, and its use as a geobarometer. Contribution to Mineralogy and Petrology, 77, 185-194.

Ozawa, K. (1997) Mechanism of magma generation constrained by mantle peridotites: solid-dominant open magma system. Bulletin of the Volcanological Society of Japan, 42, special number, Magmalogy, 61-85 (in Japanese with English abstract).

Poudjom-Djomani, Y.H., Nnange, J.M., Diament, M., Ebinger, C.J. and Fairhead, J.D. (1995) Effective elastic thickness and crustal thickness variations in west central Africa inferred from gravity data. Journal of Geophysical Research, 100,
22047-22070

Poudjom-Djomani, Y.H., Diament, M. and Wilson, M. (1997) Lithospheric structure across the Adamawa plateau (Cameroon) from gravity studies. Tectonophysics, 273, 317-327.

Quick, J.E. (1981) The origin and significance of large, tabular dunite bodies in the Trinity peridotite, northern California. Contribution to Mineralogy and Petrology, 78, 413-422.

Ringwood, A.E., (1966) The chemical composition and origin of the Earth. In Advances in Earth Sciences edited by P. M. Hurley, MIT Press, Cambridge, Mass, 287-356.

Takahashi, E. and Kushiro, I. (1983) Melting of a dry peridotite at high pressure and basalt magma genesis. American Mineralogist, 68, 859-879.

Takahashi, E., Shimazaki, T., Tsuzaki, Y. and Yoshida, H. (1993) Melting study of a peridotite KLB-1 to $6.5 \mathrm{GPa}$, and the origin of basaltic magmas. Philosophical Transactions of the Royal Society, London, A, 342, 105-120.

Takahashi, N. and Arai, S. (1989) Textural and chemical features of chromian spinel-pyroxene symplectites in the Horoman peridotites, Hokkaido, Japan. Science Reports of the Institute of Geoscience, University of Tsukuba, 10, 11-17.

Tamura, A., Makita, M., and Arai, S. (1999) Petrogenesis of ultramafic rocks in the Kamuikotan belt, Hokkaido, northern Japan. The memoirs of the Geological Society of Japan, 52, 53-68 (in Japanese with English abstract).

Uzuakpunwa, A.B. (1974) The Abakaliki pyroclastics, Eastern Nigeria: new age and tectonic implications. Geological Magazine, 111, 65-70.

Vidal P., Dupuy, C., Maury, R.C. and Richard, M. (1989) Mantle metasomatism above subduction zones: trace element and radiogenic isotope characteristics of peridotite xenoliths from Batan Island (Philippines). Geology, 17, 1115-1118.

Wells P.R.A. (1977) Pyroxene thermometry in simple and complex system. Contribution to Mineralogy and Petrology, 62, 129-139.

Manuscript received March 4, 2009

Manuscript accepted October 10, 2009

Published online March 4, 2010

Manuscript handled by Masaaki Obata 